\title{
Editor's Note Regarding the Current Pandemic
}

Published online: 27 May 2020

(C) Springer Science+Business Media, LLC, part of Springer Nature 2020

As the April number was being finalized on April 4, a potential submission was sent to the editors via email. It captured very beautifully what so many of the readers and contributors to Human Ecology are currently experiencing. We decided it had to go in this issue with only an in-house review. Adriano Sofo, a professor of plant biology at the University of Basilicata, is sheltering at home in Matera, southern Italy with his family. At this time almost all academic editors and board members of this journal, the Springer editors and office per-

Daniel G. Bates

Editor
Ludomir Lozny

Managing Editor sonnel, not to mention most of those who review and contribute, are in their widely scattered and separated homes. Our students and colleagues communicate electronically. The main offices of Springer in New York City are presently shuttered. Adriano Sofo, as we see in his submission, part opinion piece, part self help advisory and part science, is experiencing what is affecting the natural science community worldwide.

His message resounds: Stay well; stay cheerful; and stay intellectually engaged!

Publisher's Note Springer Nature remains neutral with regard to jurisdictional claims in published maps and institutional affiliations 